\title{
Seagrass coverage and associated fauna at Gaya Island, Sabah, Malaysia: A pilot seagrass transplantation
}

\author{
Ejria Saleh $^{1 *}$, Tzuen Kiat Yap' ${ }^{1}$ and John Barry Gallagher ${ }^{2}$ \\ ${ }_{1}^{1}$ Borneo Marine Research Institute, Universiti Malaysia Sabah, Jalan UMS, 88400 Kota Kinabalu, Sabah, Malaysia \\ 2Institute of Marine and Antarctic Studies, University of Tasmania, 7004 Hobart Tasmania Australia.
}

*Corresponding author: ejsaleh@ums.edu.my

\begin{abstract}
Seagrasses provide a range of marine ecosystem services. These include coastal protection, biodiversity, provision of food for various organisms, breeding and nursery habitats for many marine species, and carbon storage. Increasing anthropogenic pressures have contributed to the decline of seagrass habitats. Transplantation is one of the solutions to increase seagrass coverage and resilience. What is often overlooked, however, is the ability of this tropical ecosystem to attract and support faunal assemblages that may impinge on the success of the transplantation. A pilot study on seagrass transplantation at Gaya Island (Kota Kinabalu, Sabah) was intended for observing its stability and species of fauna that develop association with this vegetation. The study covered the southwest and northeast monsoons. Mixed seagrass species were planted on approximately $50 \%$ of $30 \mathrm{~m} 2$ transplantation areas. Monitoring of the planted seagrass was carried out in five phases (T1-T5) from September 2016 to April 2018. Weekly observations were made by SCUBA diving. Identification of associated fauna was done on the spot and was based on morphological characteristics. During the T1 (September to December 2016) the seagrass coverage was reduced to $41 \%$ due to strong waves generated by the northeast monsoon. However, the seagrass coverage increased ( $66 \%$ ) during the southwest monsoon (T2 - T4) in 2017. In early 2018 (T5), the seagrass coverage again reduced (about 18\%) due to strong waves but recovered again at the end of the monitoring period (April 2018). A total of 30 species of fauna that were identified consisted of 9 resident and 21 non-resident species. Physical structure of transplanted seagrass created a microhabitat, and increased the food availability and abundance, which attracted many species of different trophic levels.
\end{abstract}

Keywords: Fauna, Behaviour, Seagrass, Transplanting, Monsoon, Gaya Island

\section{Introduction}

Seagrass ecosystems provide a number of important coastal ecosystem services. These include coastal protection, provision of food for marine species, including some endangered ones (Yaakub et al., 2018) and exceptional carbon storage ability (Fourqurean et al., 2012) compared to terrestrial forests. The increase in anthropogenic pressures in the coastal areas has contributed to declining and fragmentation of seagrass meadows. This has resulted in global degradation at a rate of $7 \%$ annually, with a loss of approximately $35 \%$ of the world seagrass meadows (Waycott et al., 2009). It is also estimated that by the year 2100 , the rate of loss of seagrass in tropical Pacific will be in the range of $5-35 \%$ annually (Brodie and Antoine, 2018. In turn, this could be expected to directly affect the fish abundance and availability within the coastal area.

In Kota Kinabalu coastal waters, 11 seagrass species scattered along its coastline and nearby islands have been reported (Murshidi et al., 2018; Edang, et al., 2008). The Malaysian Census 2010 estimated that the population of Kota Kinabalu was 39,110 people (Statistics Department, 2010). This exerts a major impact on the already stressed coastal seagrass ecosystems. When this is coupled with poor catchment management and unplanned coastal developments the very resilience of existing seagrass meadows is seriously threatened. For example, eutrophication reduces the available light for their growth (Ralph et al., 2007), overfishing and environmental pollution result in decline in seagrass community diversity, and in turn reduce any associated ecosystem services (Jackson, 2001). The coastal developments can only restrict the necessary migration landward as sea levels continue to rise.

One of the solutions to restore seagrass ecosystem is through transplantation (active restoration). In Malaysia, there was only one seagrass experimental transplantation reported in Setiu Wetlands, Terrengganu, using shells as anchoring the device (Gan, 2011). Borneo Marine Research Institute (University Malaysia Sabah) and Marine Ecology Research Centre (MERC) had taken an initiative to replant seagrass in the Gaya Island, Kota Kinabalu. This initiative was carried out to replenish a seagrass ecosystem that was lost a few years back in Malohom Bay.

Lessons on how fauna assemblages change during development and expansion of restored seagrass beds may in part be gained from studies that have focussed on different seagrass configurations (Salita et al., 2003), density of shoots, seagrass coverage, biomass, patchiness and land scape (Healey and Hovel, 2004). Particularly relevant to early stages of transplantation are the observations that small patchy stands of seagrass create a microhabitat that is 
favoured by epifauna compared to the long continuously meadows (Thorhaug, 1986; Bloomfield and Gillanders, 2005). How new seagrass beds growth and create a microhabitat require monitoring and sustained studies. However, in most seagrass transplantation activities and projects across the globe, marine fauna settlement had not been included in the monitoring (van Katwjik et al., 2016). This study will help to understand the interaction between seagrass and associated fauna, identify positive or negative impacts on the transplanted seagrass and utilise the observed ecological relationships to accelerate recovery of seagrass beds. Importance of such studies has been highlighted by Gagnon et al. (2020). The objectives of this study are to observe the seagrass coverage and identify associated fauna at the newly transplanted seagrass bed.

\section{Methodology}

A total of five seagrass shoots of Halophila ovalis, Enhalus acoroides, Cymodocea serrulata, Cymodocea rotundata and Halodule uninervis were collected from a donor site at Gaya Bay, Gaya Island (Figure 1). The seagrass shoots were planted inside the husbandry tanks at Marine Ecology Research Centre (MERC) located in the Malohom Bay) for seagrass conditioning (Yap et al., 2020). This process allows the development of seagrass roots in the new substrate before transplanting in the the natural environment. After two months in the husbandry tanks, the conditioned seagrass shoots were transplanted to the adjacent intertidal areas. MERC is one of the tourist destinations in Gaya Island, and its surrounding marine areas are protected by the Gayana Eco Resort. Tourists have encountered abundance of fishes and turtles while snorkelling or diving in this area. The planted site is where a thriving seagrass bed once existed but was lost several years ago.

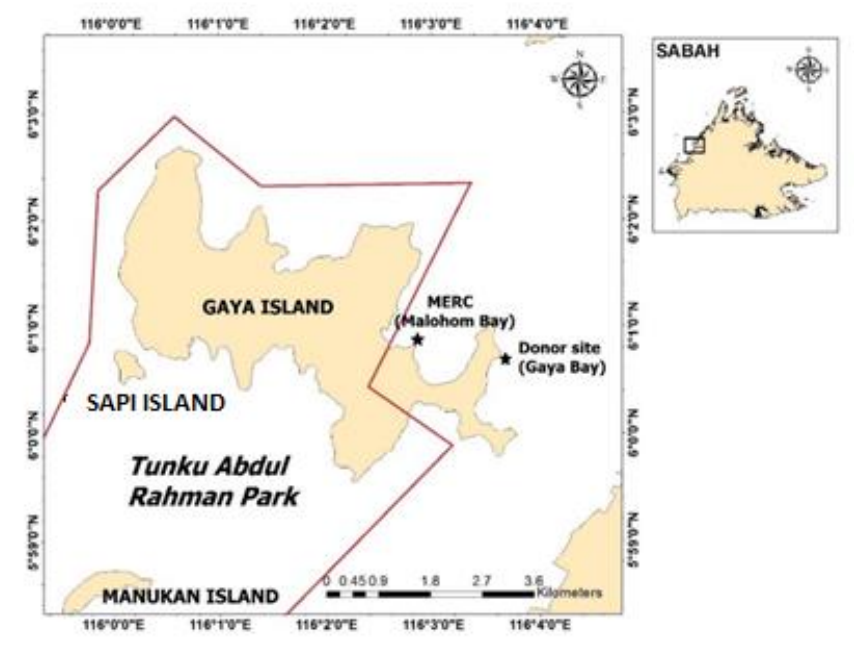

Figure 1. Location of the seagrass donor site (Gaya Bay) and transplanting area (Malohom Bay) at Gaya Island.

Size of the seagrass planting area was approximately $30 \mathrm{~m}^{2}$ and this was protected by eight turtle excluder cages. The cages ( $2 \mathrm{~m} \times 2 \mathrm{~m} \times 1 \mathrm{~m}$ each) were made up of a plastic fence with a mesh size of $2 \mathrm{~cm}$. The thick algae growing on the cages were occasionally cleaned to allow better sunlight penetration and active photosynthesis. About 40-60 mixed species of seagrass shoots were transplanted with an initial coverage of approximately $50 \%$ inside each of turtle excluder cage.

Observation and identification of associated marine fauna in the transplanted site were initiated from September 2016 to April 2018 (20 months). Weekly changes in the seagrass coverage (percent cover) were estimated while the associated fauna of the seagrass was identified on the spot or based on the pictures taken from the field. The behaviour of the fauna in term of their territorial preferences, swimming, hiding, solitary living or aggregation were also recorded. These observations were conducted during SCUBA diving for approximately 30 minutes during each trip. Associated marine fauna was identified based on morphological characteristics to the lowest taxa as far as possible and the identified species were categorised as resident (R) or nonresident $(\mathrm{N})$ to the seagrass. The resident fauna were those that were constantly observed in the transplanted seagrass or were seen hiding in the seagrass canopy continuously for at least 3 weeks while the species were considered nonresident if they visited the transplanted seagrass for foraging and constantly move between seagrass and non-vegetative seafloor.

The findings were summarized in five phases over four months (T1: September - December 2016, T2: January April 2017, T3: May-August 2017, T4: September - December 2017 and T5: January - April 2018). This study was designed to cover the northeast and southwest monsoons from November to February and April to August, respectively (Akhir, 2012). The observations were also covered the intermonsoon season in March and October.

\section{Results and Discussion}

\section{Seagrass coverage and fauna behaviours}

The percent coverage of the transplanted seagrass declined over time (phase T1): September to December 2016. Coverage of living seagrass was reduced to $22 \%$ in December 2016 due to erosion caused by the waves in the northeast monsoon season (Figure 2). This uprooted most of the transplanted seagrass. Such a situation has also been reported with the transplanted seagrass in the Philippines (Calumpong et al., 1996). Interestingly, schools of adult (more than $10 \mathrm{~cm}$ body length) parrotfish, scad and rabbitfish were observed grazing the overgrown algae on the turtle excluder cage (Table 1). Studies on the efficiency of this opportunistic cleaning behaviour could be another topic for future research on seagrass plantation. It required more efforts towards maintaining the turtle excluder cage, and reducing human disturbances on the transplanted seagrass in much the same way as in coral farming or rehabilitation (Frias-Torres et al., 2015; Nithyanandan et al., 2018). 


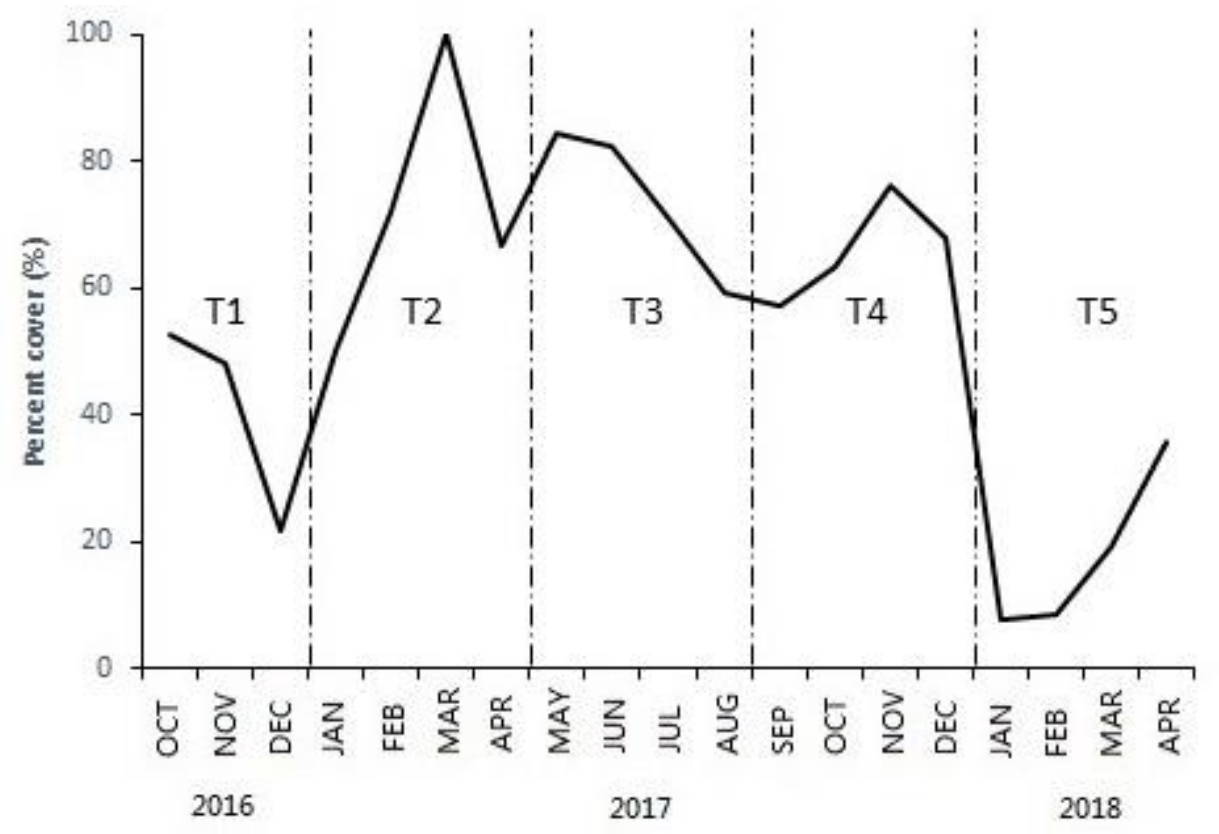

Figure 2. Percent coverage of transplanted seagrass from September 2016 to April 2018.

Table 1. Observations on the behaviour of marine fauna associated with the transplanted seagrass..

\section{No Name /species No of species Observation / behaviour}

1 Threadfin cardinalfish

1

$2 \quad$ Highfin fang benny

1

3 Sea bream

3

$4 \quad$ Longfin grouper

5

Damselfish

2

6 Rabbitfish

$7 \quad$ Scorpionfish

1

8 Pufferfish

1

9 Green turtle
A total of four size class of fish observed. The largest adults with body length approximately $8 \mathrm{~cm}$ were brooding eggs in their mouth. Another three size class observed are $6 \mathrm{~cm}, 4 \mathrm{~cm}$, and $2 \mathrm{~cm}$. Constantly swimming closely or among seagrass canopy.

Swimming in vertical among seagrass canopy as it mimics drifting seagrass leaf. Most of the time clinging on seagrass leaf.

Foraging in the sediment and from disturbed sediment during seagrass transplanting.

Hide among coral rubbles or near to turtle excluder cage. The present of this grouper probably attracted to the high number of cardinalfish found in the restored seagrass bed.

Territorial behaviour - selectively chasing off herbivore fish (parrotfish and rabbitfish) away from their burrow or coral rubble within transplanted seagrass site.

Adults fish are grazing on overgrown algae on the turtle excluder cage while juvenile fish (1-3 cm size) slip into the cage and nibbling on epiphytes and seagrass $H$. ovalis.

Camouflage among rocks, coral rubbles or in the sediment among the seagrass.

Juvenile individual with a size of approximately 1-3 cm and occasionally spotted among seagrass canopy.

Occasional sighting in Maholom Bay. It was sighted grazing and uprooting the unprotected seagrass during the first time period (T1). 
Table 2. Seagrass features and associated marine fauna during the five phases (T1-T5).

\section{Phase}

Time period $\mathrm{T} 1$

(September -

December 2016)

Time period T2 (January - April 2017)

Time period T3 (May - August 2017)

Time period T4 (September -

December 2017)

Time period T5 (January - April 2018)

\section{Seagrass characteristics}

Seagrass coverage increased with fastgrowing Halophila ovalis, while other 4 four species remain the same. Seagrass coverage was decline rapidly in December 2016 during the northeast monsoon season.

Fast growing, $H$. ovalis repopulate the area after February 2017, increasing seagrass coverage to $100 \%$ in March 2017 (Figure 2).

Seagrass Cymodocea serrulate formed denser meadows expand and formed a network of rhizome and shoots, only $H$. ovalis was selectively grazed by herbivore fish, reduce coverage to $60 \%$ (Figure 2).

Seagrass in good condition (coverage > 60\%) but declining in December 2017 due to strong wave during northeast monsoon season. Turtle excluder cages damaged and two were uprooted.

Low seagrass cover below 25\% uprooted due to the northeast monsoon. Halophils ovalis was slowly recovered, together with survived $C$. serrulata increased coverage to $35 \%$ (Figure 2).

\section{Associated marine fauna}

Schools of parrotfish, scat and rabbitfish grazing overgrown algae on the turtle excluder cage. Small snails observed in the sediment within seagrass area, following hermit crab that utilised that snail shell as shelter. Non-resident fish such as wrasses, sea bream foraging within seagrass and unvegetated sediment.

A small group of cardinalfish resident within transplanted seagrass. Territorial fish, white and black damselfish fish chasing off herbivore fish from transplanted seagrass area

Adult cardinalfish brooding eggs in the mouth and comprising of four different size class $(2,4,6$ and $8 \mathrm{~cm}$ ) individuals. The population of cardinalfish was estimated, 1000 individuals.

Predators such as grouper resident within transplanted seagrass bed. Scorpionfish was occasionally sighted hiding among seagrass canopy. Sea urchin in adjacent coral moving closer to transplanted seagrass, and some manage to slip into the cage.

All of the fish population disappeared in the beginning of T5..
Seagrass began to repopulate the transplanted site from the end of the northeast monsoon (Phase T2: January April 2017). The fast horizontal expansion of the colonizer species, Halophila ovalis, occupied the spaces between seagrass shoots that survived, and increased the coverage to $100 \%$ (when the entire plot was covered by H. ovalis) in March 2017 (Figure 2). The coverage of the remaining species that survived, namely, Enhalus acoroides, Cymodocea serrulata and Halodule uninervis, remained the same. During this phase, a small group of cardinalfish was seen resident in the transplanted seagrass and it existed with the territorial species such as white and black damselfish fish. They were observed to chase off the herbivore fish from their territory (Table 1).

During the third phase (Phase T3: May-August 2017) it became apparent that $H$. ovalis was grazed by herbivorous fish. The damselfish started disappearing from the transplanted seagrass bed, and only petiole and rhizome were observed to be intact in the sediment. This activity could be the reason for a $60 \%$ decrease in the coverage in August 2017 (Figure 2). In addition, juvenile rabbitfish and parrotfish were also observed nibbling on the leaves $H$. ovalis.
This is a similar finding as reported by Lee et al. (2016) where more than $75 \%$ of $H$. ovalis was lost due to grazing, and when those herbivore fish utilised seagrass meadows as foraging ground instead of as a refuge habitat (Statton et al., 2015). Selective grazing by herbivores depended on the abundance and availability of seagrass leaves, palatability and secondary metabolite production (Prado, et al., 2010). Herbivorous species such as rabbitfish are equipped with amino acid receptors, helping them to choose a diet from several species of macrophytes (Pillans et al., 2004). Nevertheless, in spite of some grazing pressure, the seagrass, C. serrulata, began a significant colonial expansion through shoots and rhizomes (Table 2). There was no significant change in E. acoroides and $H$. uninervis coverage during this phase.. The population of cardinalfish increased to an estimated 1000 individuals, comprising four different size classes. During this stage, adult cardinalfish living in the transplanted seagrass beds were seen brooding their eggs in the mouth. Significance of this biological feature was not clear but it pointed to the sufficient food resources available to support their breeding, possibly from the newly transplant stands. 
The seagrass continued to expand its shoots while being constantly grazed by herbivores during the fourth phase (Phase T4: September - December 2017). The coverage was $57-76 \%$ (Figure 2). The presence of predators (grouper and scorpion fish) during this phase indicated that prey species were available in this seagrass habitat (Table 1). An abundance of cardinalfish most likely attracted higher trophic level predators such as the grouper to the transplanting site. The grouper is listed as one of the commercial demersal fish in Malaysia (Mat-Piah et al., 2018). This species is also popular in Live Reef Food Fish Trade (LRFT) around Kota Kinabalu and is highly targeted for supply to seafood restaurants. Overfishing, destructive fishing and habitat losses have led to a rapid decline in the population of groupers in this area (Khatib, 2015).

According to Saleh et al. (2010), wave heights recorded on the west coast during the northeast monsoon are in the range of $0.9-1.2 \mathrm{~m}$. The wave heights reduce to less than $0.9 \mathrm{~m}$ during the southwest monsoon. During the northeast monsoon, towards the end of December 2017, the seagrass coverage was reduced (Figure 2). The stormy conditions could have been the driving force for their uprooting. Only $C$. serrulata and $H$. ovalis survived these rough sea conditions to some extent. Their coverage was 8\% in January 2018 but slowly recovered to 35\% in April 2018 (Phase T5: January April 2018) (Figure 2). During this event, the associated fauna disappeared from the transplanted site. The reasons are unclear as it could be due to a variety of factors, including loss of seagrass or strong wave action during the northeast monsoon.

Transplanted seagrass created habitat to support associated fauna compared to the un-vegetated habitats (Thorhaug, 1986; Salita et al., 2003; Ambo-Rapper, 2016). In the same period of time, some species of the fauna can accelerating seagrass growth and recovery. Supporting natural recovery of the habitats is a better approach compared to transplantation. If this can be achieved then many problems facing this marine critical habitat can be addressed. Seagrass-bivalves interaction can achieve mutual benefits and accelerate the seagrass growth and recovery (Gagnon, et al., 2020). Epifaunal bivalves can help attenuate wave energy and stabilize sediment, which would allow seagrass to establish and develop the below-ground biomass. Their filter feeding on plankton and particles from water column can be aided by a better light penetration for photosynthesis of the seagrass.

\section{Associated fauna at seagrass pilot transplantation site}

During the 20 months of observations, a total of 30 species of fauna were identified in the seagrass transplantation site. Out of these $30 \%$ of these species were categorised as resident (Appendix 1). The complexity of physical structure of seagrass canopy creates microhabitat to support various small and medium sized fauna (Thorhaug, 1986; Salita et al., 2003; Ambo-Rapper, 2016). In addition, seagrass canopy attracted more zooplankton (Chavanich et al., 2004) and provided a substrate for secondary production or the growth of epiphytes. This increases the food availability and abundance (Nanjo et al., 2014), and helped in attracting small and juvenile fish such as cardinalfish, high-fin fang benny that hide and camouflage among the seagrass leaves, and the pufferfish. Seagrass-bivalve interaction can achieve mutual benefits and accelerate the seagrass growth and recovery (Gagnon et al., 2020). Epifaunal bivalves can also help attenuate wave energy and stabilize the sediment to facilitate the below-ground biomass. Future seagrass restoration should consider the seagrass-bivalve interaction for enhancing the success of transplantation efforts.

The number of species of the fauna and observations of their behaviour are presented in Table 2 . It is evident from the data that there were as many as 23 species of fishes, while the rest were in smaller numbers (echinoderms, 3;crabs, 2;gastropod, 1; reptile, 1). Grouper and scorpion fish, both predatory, appeared to reside in the transplantation site during September - December 2017. This indicated the availability of prey species in this new seagrass habitat at least in this period. The green turtle, known for grazing on seagrasses (Andre et al., 2005), was observed foraging on unprotected or newly transplanted seagrass in the initial phase (Phase T1). After setting up the turtle excluder cages to protect the newly planted seagrass there was no turtle sightings.

\section{Conclusions}

Seagrass transplantation in Gaya Island showed interesting results. The fast growing species (Halophila sp.) as well as others formed dense canopy to create macro- and -mesohabitats that attracted different species of marine fauna. The percentage coverage of the seagrass in the 5 phases of observations fluctuated due to both impacts of seasonal monsoon and biological factors. The average coverage was less than $41 \%$ after the northeast monsoon and increase to $66 \%$ from inter-monsoon to southwest monsoon. The planted seagrass attracted about 30 species of fauna (9 resident and 21 non- resident species) during the 20 months of observations. This included fish species of small size (for example, cardinalfish) and the predators. The habitat was also used by species that became resident. The number of recorded fauna species could be higher if the monitoring is extended over the night, and during different tidal cycles and weather conditions.

If successful, the seagrass transplantation can help in building resilience in the coastal-marine ecosystem and support marine biodiversity by providing ecosystem services to species of different trophic levels. A biodiverse marine ecosystem will undoubtedly support sustainable fisheries and help the local communities subsisting on marine resources. Careful planning and scientific knowledge can increase the chances of success of transplanted seagrasses. In this region of Sabah, the month of March is suitable since it is past the peak of northeast monsoon and sea conditions are not harsh for the new seagrass bed. 


\section{Acknowledgement}

This project was funded by the Ministry of Higher Education (MOHE) through Project FRGS0424-SG-1/2015. We thank Universiti Malaysia Sabah and Marine Ecology Research Centre, particularly Dr. Robert Tan and Mr. Alvin Wong, for providing facilities for this study.

\section{References}

Andre, J., Gyuris, E., \& Lawler, I.R. (2005). Comparison of the diets of sympatric dugongs and green turtles on the Orman Reefs, Torres Strait, Australia. Wildlife Research 32(1), 53-62.

Ambo-Rappe, R. (2016). Differences in richness and abundance of species assemblages in tropical seagrass beds of different structural complexity. Journal of Environmental Science and Technology 9, 246256.

Akhir, M.M.F. (2012). Surface Circulation and Temperature Distribution of Southern South China Sea from Global Ocean Model (OCCAM) (Peredaran Permukaan dan Taburan Suhu Selatan Laut China Selatan melalui Model Lautan Global (OCCAM). Sains Malaysiana 41(6), 701-714.

Bloomfield, A.L. \& Gillanders, B.M. (2005). Fish and invertebrate assemblages in seagrass, mangrove, saltmarsh and nonvegetated habitats. Esturaries 28(1) 63-77.

Brodie, G., \& Antoine, N.Y. (2018). Effects of climate change on seagrasses and seagrass habitats relevant to the Pacific Islands. Science Review, 112-131.

Calumpong, H.P., Menez, E.G. \& Phillips, R. (1996). Factors affecting survival and growth of reciprocal seagrass transplants on Negros Island, Central Philippines In: J. Kuo, D.I. Walker \& H. Kirkman (eds.), Seagrass Biology: Scientific Discussion from an International Workshop. Rottnest Island, Western Australia, 25-29 January 1996. The University of Western Australia, Nedlands, Western Australia.

Chavanich, S., Phiu-On, W. \& Viyakarn, V. (2004). Colonization of marine zooplankton and epifauna on artificial seagrass beds with different morphology. The Natural History Journal of Chulalongkorn University 4,101-103.

Edang, L. Razak, A.R.F \& Fah, N.A.A. (2008). Rumput Laut Perairan Sabah. Dawama Sdn. Bhd. Ampang.

Fourqurean, J.M., Duarte, C.M. \& Kennedy, H. (2012). Seagrass ecosystems as a global significant carbon stock. Nature Geoscience 5(7), 505-509.

Frias-Torres, S., Goehlich, H., \& Reveret, C. (2015). Reef fishes recruited at midwater coral nurseries consume biofouling and reduce cleaning time in Seychelles, Indian Ocean. African Journal of Marine Science 37, 421-426.

Gagnon, K., Rinde, E., \& Bengil, E.G.T. (2020). Facilitating foundation species: The potential for plant-bivalve interactions to improve habitat restoration success. Journal of Applied Ecology 2020:00:1-19.

Gan, S.H. (2011). Transplantation of Halodule pinifolia using shell as anchoring device in Setiu, Terengganu. BSc Thesis (Marine Biology). University Malaysia Terengganu. Kuala Terengganu.

Healey, D. \& Hovel, K. A. (2004). Seagrass bed patchiness: effect on epifaunal communities in San Diego Bay, USA. Journal of Experimental Marine Biology and Ecology 313 (1), 155-174.

Jackson, J. B. (2001). What was natural in the coastal oceans? Proceedings of the National Academy of Science 98 (10), 5411-5418.

Khatib, M.A.B.M. (2015). A mini review on the present status of the marine fisheries in Sabah, Malaysia. Aquaculture and Marine Biology 2 (4), 1-6.
Lee, C.L., Huang, Y.H., \& Chen, C.H. (2016). Remote underwater video reveals grazing preferences and drift export in multispecies seagrass beds. Journal of Experimental Marine Biology and Ecology 476, 1-7.

Mat-Piah, R., Kamaruddin, A., Abdul-Kadir, N.H. \& Azaman, M.N. 2018. Analysis of historical landing data to understand the status of grouper populations in Malaysia. Malaysian Applied Biology 47(3):49-58. Murshidi, A., Yap T. K., Gallagher, J. B. \& Saleh, E. (2018). Seagrass meadow impacts on Universiti Malaysia Sabah (UMS) Beach, Kota Kinabalu, Sabah (Malaysia). Journal of Tropical Biology and Conservation 15: 189-201.

Nanjo, K., Kohno, H., \& Nakamura, Y., (2014). Differences in fish assemblage structure between vegetated and un-vegetated microhabitats in relation to food abundance patterns in a mangrove creek. Fish Science 80, 21-41.

Nithayanandan, M., Le Vay, L., Raja, D.K., Kesavan, R. \& Pereira, D. (2018). Coral nursery and transplantation of staghorn coral, Acropora downingi in Sabah Al-Ahmad Sea City, Kuwait, Arabian Gulf. Cogent Environmental Science 4 (14), 1-15.

Prado, P., Romero, J. \& Alcoverro, T. (2010). Nutrient status, plant availability and seasonal forcing mediate fish herbivory in temperate seagrass beds. Marine Ecology Progress Series 409, 229-239.

Pillans, R.D., Franklin, C.E., \& Tibbetts, I.R. (2004). Food choice in Siganus fuscences: influence of macrophytes nutrient content and availability. Journal of Fish Biology 64, 297-309.

Ralph, P.J., Durako, M.J., \& Enriquez, S. (2007). Impact of light limitation on seagrass. Journal of Experimental Marine Biology and Ecology 350 (1-2), 176-193.

Saleh, E, Beliku, J., Aung, T. \& Singh, A. (2010). Wave Characteristics in Sabah Waters. American Journal of Environmental Sciences 6 (3): 219 223.

Salita, J.T., Ekau, W. \& Saint-Paul, U. (2003). Field evidence on the influence of seagrass landscapes on fish abundance in Bolinao, Northern Philippines. Marine Ecology Progress Series 247, 183-195.

Statistics Department Malaysia. 2010. The Malaysian Census 2010. Statistics Department, Putrajaya.

Statton, J., Gustin-Craig, S., \& Dixon, K.W. (2015). Edge effects along a seagrass margin result in an increased grazing risk on Posidonia australis transplants. PlosONE 10(10): e0137778.

Thorhaug, A. (1986). Review of seagrass restoration efforts. Ambio 15(2), 110-117.

van Katwijk, M.M., Thorhaug, A., \& Marba, N. (2016). Global analysis of seagrass restoration: The importance of large-scale planting. Journal of Applied Ecology 53(2), 567-578.

Waycott, M., Duarte, C.M., \& Carruthers, T.J.B. (2009). Accelerating loss of seagrasses across the globe threatens coastal ecosystems. Proceedings of the National Academy of Sciences 106(30), 12377-12381.

Yaakub, S.M., Ooi, J.L.S., \& Buapet, P. (2018). Seagrass research in Southeast Asia. Botanica Marina 61(3), 177-179.

Yap, T.K., Saleh, E. \& Gallagher, J.B, 2020. Impacts of associated fauna on seagrass during the condtining period in husbandary tanks: Gaya Island, Sabah, Malaysia Case. Transections on science and technology, 7(2), 5057. 